\title{
Cattle infestation by lice in Northern Tunisia
}

\author{
Mohamed Gharbi ${ }^{1 *}$ Wiem Labibi ${ }^{1}$ \\ Mohamed Jedidi ${ }^{1}$ Mohamed Zouari ${ }^{2}$
}

\section{Keywords}

Cattle, Phthiraptera, Linognathus vituli, Bovicola bovis, Haematopinus eurysternus, Tunisia

Accepted: 17 January 2020

Published: 11 May 2020

DOI: $10.19182 /$ remvt.31860

\begin{abstract}
Summary
The reported study was carried out from October 2014 to January 2015 and involved 622 cattle belonging to a dairy farm in North Tunisia. Each animal was examined once for the presence of lice. The infestation prevalence was estimated at $14.3 \%(89 / 622)$. Three louse species were collected: Linognathus vituli $(2.7 \%)$, Haematopinus eurysternus (11.4\%) and Bovicola bovis (0.8\%). The co-infestation prevalence was $0.6 \%$ and concerned only B. bovis and L. vituli, collected from four calves (three males and one female). Calves were infested by the three species, L. vituli $(17.5 \%)$, B. bovis $(5.2 \%)$ and $H$. eurysternus $(1.0 \%)$, whereas adults were only infested by $H$. eurysternus $(13.3 \%)$. All $H$. eurysternus parasites were found on the tail of the animals, whereas $L$. vituli was present on the whole body. B. bovis infested the anterior body parts, mainly the dorsal region $(60 \%)(p<0.05)$. Clinical signs were observed only in calves under six months. The infested calves showed pruritus (63\%) and depilation (37\%).
\end{abstract}

- How to quote this article: Gharbi M., Labibi W., Jedidi M., Zouari M., 2020. Cattle infestation by lice in Northern Tunisia. Rev. Elev. Med. Vet. Pays Trop., 73 (2): 141-144, doi: 10.19182/remvt.31860

\section{INTRODUCTION}

Cattle production represents a very important economic activity in all African countries, allowing both daily (milk sale) and occasional (animal sale) cash income to rural populations. Animal breeding significantly decreases because of rural depopulation, an important problem in all African countries. Cattle breeding also has a social role. For example, in a village in Chad called Bagirmi (in Arabic cattle is bagar and one hundred is mia), the poverty threshold is considered to be the ownership of 100 head of cattle.

The cattle industry is still facing several health problems in Africa. Veterinary authorities, field veterinarians and farmers pay more attention to diseases with high morbidity and lethality such as foot and mouth disease, brucellosis or tuberculosis. On the other hand, endemic parasitic diseases (ectoparasites, gastrointestinal and hemoparasitic infections), which induce lower losses but may concern a high percentage of the population and may last for several years (sometimes the whole life of the animal) are often neglected. For instance, animals infested by ectoparasites are not considered sick and they do not therefore receive specific health care. Among the

\footnotetext{
1. Laboratoire de parasitologie, Univ. Manouba, Institution de la recherche et de l'enseignement supérieur agricoles, Ecole nationale de médecine vétérinaire de Sidi Thabet, 2020 Sidi Thabet, Tunisie.

2. Office des terres domaniales, Tunis, Tunisie.

* Corresponding author

Email: gharbim2000@yahoo.fr
}

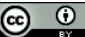

https://creativecommons.org/licenses/by/4.0/ ectoparasites, cattle can be infested by four louse species, one is a chewing louse (Bovicola bovis) and the others are sucking lice (Linognathus vituli, Solenopotes capillatus, Haematopinus eurysternus) (Dorchies et al., 2012). Louse infestation is an increasing problem as a deltamethrin-resistant Bovicola bovis population has been reported since 2014 in the United Kingdom (Sands et al., 2015).

Cattle population in North Africa has been relatively constant in recent years with 2.8, 1.6 and 0.6 million in Morocco, Algeria and Tunisia, respectively (Sraïri et al., 2013). The only study regarding louse infestation in Tunisian cattle was published by Gharbi et al. (2013), who estimated the prevalence in Northeast Tunisia at $4.7 \%$. This first study was performed in small extensive farms and involved cattle of different breeds. No survey was carried out in Tunisian intensive farms where animals belong to exotic breeds and are supposed to receive good health care. The aim of this study was thus to estimate the different parasitological indicators regarding louse infestation in an intensive farm of Northern Tunisia.

\section{MATERIALS AND METHODS}

\section{Study region and animals}

The present study was carried out in Mateur (Bizerte District, North Tunisia) which is located in the subhumid area. The mean temperatures in winter and summer are $7^{\circ} \mathrm{C}$ and $32^{\circ} \mathrm{C}$, respectively. The mean yearly rainfall varies between 600 and $800 \mathrm{~mm}$.

The survey was carried out from October 2014 to January 2015 in a Holstein-Friesian intensive cattle farm. A total of 622 cattle (525 cows, 36 male calves and 61 female calves) were examined, each 
on one occasion. The animals were on average 4.5 years old (range: 1 day - 11 years).

All the animals were examined for the presence of lice according to the method of Colwell et al. (2001). Briefly, the whole body of each animal was inspected for the presence of lice. In addition, seven anatomical regions were minutely inspected: dewlap, cheeks, muffle, eyes, withers, back line and tail. During the inspection, the hairs were moved apart for careful examination of the skin and of the bottom part of the hairs; for each site, this operation was repeated 4-5 times on a $5-\mathrm{cm}^{2}$ area.

All the collected parasites were kept in identified vials containing $70 \%$ ethanol. For examination, they were washed with distilled water, incubated in a $10 \%$ potassium hydroxide $(\mathrm{KOH})$ solution for two days, then washed in successive solutions of ethanol $(30,50,70,90$ and $100 \%$ concentration) for 10-15 minutes, and finally washed with xylol (Kakar and Kakarsulemankhel, 2009). Species identification was done under microscope at $100 \mathrm{x}$ magnification, according to the key of Price and Graham (1997).

\section{Parasitological indicators}

The infestation prevalence was estimated as follows (Bush et al., 1997) :

Infestation prevalence $=100 \mathrm{x}$ number of infested animals $/$ Number of examined animals.

The infestation intensity was calculated as:

Total number of lice / Total number of infested animals.

\section{Statistical analysis}

Comparisons of percentages were carried out with EPI INFO 2000 using the chi-square test at 5\% threshold.

\section{RESULTS}

\section{Infestation prevalence}

A total of 89 animals were infested by lice, corresponding to a prevalence of $14.3 \%$. Three louse species were collected: Linognathus vituli (2.7\%), Haematopinus eurysternus (11.4\%) and Bovicola bovis $(0.8 \%)$. The co-infestation prevalence was $0.6 \%$ and concerned B. bovis and $L$. vituli collected in four calves (three males and one female) (Table I).

Calves were infested by the three species (L. vituli: $17.5 \%$; B. bovis: $5.2 \%$; H. eurysternus: $1.0 \%$ ), whereas adults were only infested by H. eurysternus $(13.3 \%)$. There was no difference in infestation prevalence between male $(19.4 \%$; $7 / 36)$ and female $(19.7 \%$; $12 / 61)$ calves $(\mathrm{p}>0.05)$.

\section{Infestation intensity}

The mean infestation intensity was four lice per infested cattle. $H$. eurysternus was the most frequent species but its infestation intensity was low (1.3). On the other hand, the infestation intensity by B. bovis and $L$. vituli was relatively high (7.4 and 16.3 , respectively). Less than one-year-old calves showed the highest infestation intensity (13.8) (Figure 1).

\section{Anatomical infested regions}

All H. eurysternus were found on the tail of animals, whereas L. vit$u l i$ was present on the whole body. B. bovis infested the anterior body parts and the dorsal region $(60 \%)$ (Table II).

\section{Clinical signs}

Clinical signs caused by pediculosis were observed only in calves under six months, which expressed pruritus (63\% of the infested calves) and depilation (37\%) (Figure 2). The depilation was irregular with discrete erythema of 5-12 centimeter diameters.

\section{Table I}

Cattle infestation prevalence and intensity of different louse species in Northern Tunisia

\begin{tabular}{lcccc} 
Animal species & $\begin{array}{c}\text { Num. of } \\
\text { infested } \\
\text { calves }\end{array}$ & $\begin{array}{c}\text { Num. of } \\
\text { infested } \\
\text { cows }\end{array}$ & $\begin{array}{c}\text { Overall } \\
\text { prevalence } \\
(\%)\end{array}$ & $\begin{array}{c}\text { Overall } \\
\text { intensity } \\
\text { (range) }\end{array}$ \\
\hline $\begin{array}{l}\text { Bovicola bovis } \\
\text { Haematopinus } \\
\text { eurysternus }\end{array}$ & $5^{*}$ & 0 & 0.8 & $7.4(1-11)$ \\
$\begin{array}{l}\text { Linognathus vituli } \\
\text { Total }\end{array}$ & 1 & 70 & 11.4 & $1.3(1-14)$ \\
& $\begin{array}{c}19 / 97 \\
(19.6 \%)\end{array}$ & $\begin{array}{c}70 / 525 \\
(13.3 \%)\end{array}$ & 14.3 & \\
\hline
\end{tabular}

* Four calves were co-infested by B. bovis and L. vituli

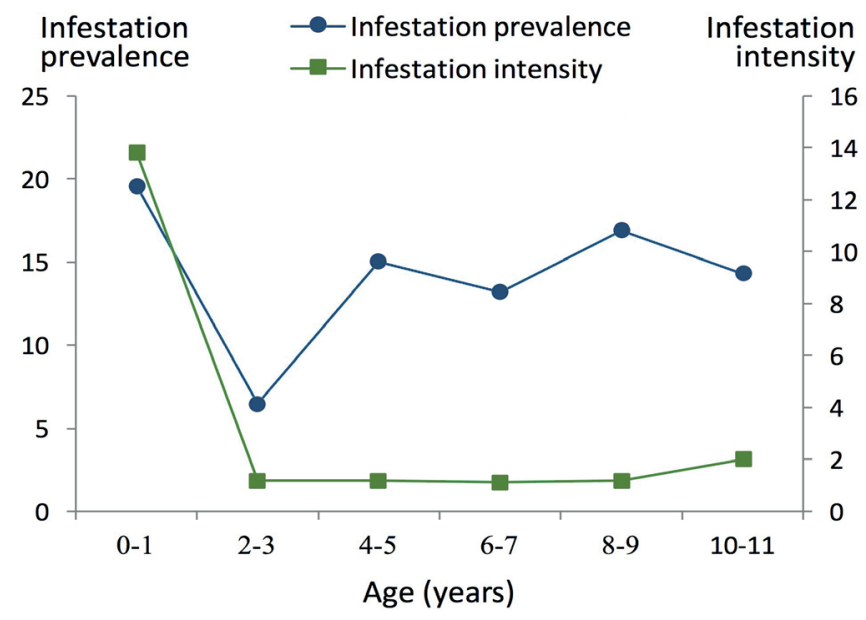

Figure 1: Louse infestation prevalence of examined cattle and intensity according to age in Northern Tunisia.

\section{Table II}

Infestation prevalence by lice according to cattle body regions in Northern Tunisia

\begin{tabular}{lccc} 
& \multicolumn{3}{c}{$\begin{array}{c}\text { Num. of positive animals } \\
\text { (prevalence in \%) }\end{array}$} \\
Body region & $\begin{array}{c}\text { Bovicola } \\
\text { bovis }\end{array}$ & $\begin{array}{c}\text { Haematopinus } \\
\text { eurysternus }\end{array}$ & $\begin{array}{c}\text { Linognathus } \\
\text { vituli* }\end{array}$ \\
Head & $1(20)$ & 0 & $3(21.4)$ \\
Neck & 0 & 0 & $1(7.1)$ \\
Shoulders + thorax & $1(20)$ & 0 & $2(14.3)$ \\
Dewlap & 0 & 0 & $1(7.1)$ \\
Dorsal line & $3(60)$ & 0 & $4(28.6)$ \\
Base of the tail + thigh & 0 & 0 & $2(14.3)$ \\
Tail & 0 & $71(100)$ & $1(7.1)$
\end{tabular}

* Data are missing on three animals 


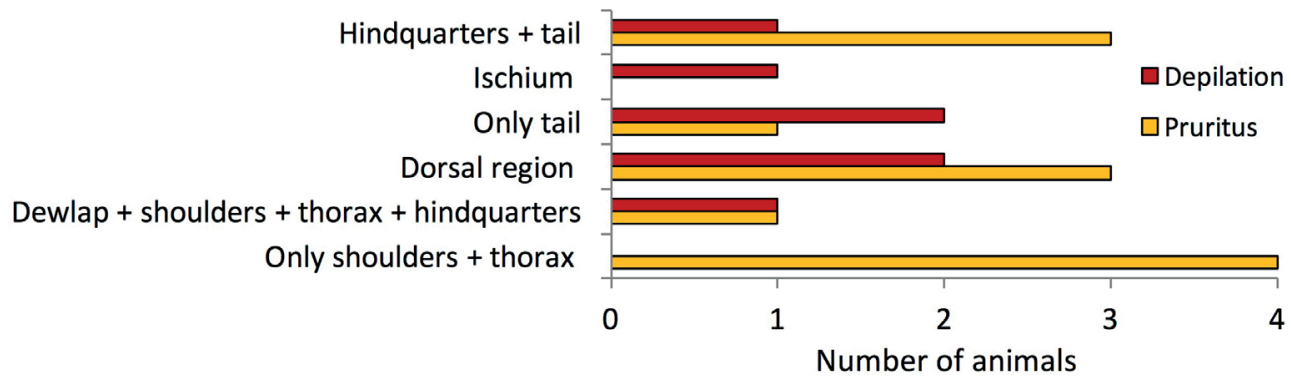

Figure 2: Localisation of clinical signs caused by louse infestation of infested calves in Northern Tunisia.

\section{DISCUSSION}

The present study was carried out in 622 cattle reared in different units of the same intensive cattle farm in Northern Tunisia. It showed that $14.3 \%$ of the animals were infested by lice. A lower infestation prevalence $(4.6 \%)$ was reported in small cattle farms in Northeast Tunisia (Gharbi et al., 2013). The difference in infestation prevalence between the two studies may be caused by several factors: low hygiene practices due to the high number of animals, abiotic factors (temperature and hygrometry) and high animal density in the intensive farm of the present study. However, the prevalence was much lower than that observed in cattle bred in other countries and under different management practices: England and Wales (75\%: Milnes and Green, 1999), Iceland (50\%: Eydal and Richter, 2010), India (33,2\%: Sanjay and Prasad, 2004), Ethiopia (31,4\%: Khumsa and Bekele, 2008), and Turkey (27,6\%: Colebrook and Wall, 2004).

Three louse species were collected: Bovicola bovis (a chewing louse), Haematopinus eurysternus and Linognathus vituli (two sucking lice or Anoplura). They were also reported by Levot (2000) in Australia. In the present study, all H.eurysternus lice were collected from cows except for one from a three-month-old calf, a trend also reported by Geden et al. (1990). On the other hand, L. vituli and B. bovis were found only in calves, as also found by other authors (Hornok et al., 2010). Few calves were co-infested by $L$. vituli and B. bovis, which was also reported by Colwell et al. (2001). Scharff (1962) studied louse infestation in Montana (USA) during three successive winters and showed that $L$. vituli was the predominant species in cattle under 18 months, and that animals older than two years were more infested by $H$. eurysternus. This is consistent with the findings of the present study. However, Kakar and Kakarsulemankhel (2009) found B. bovis in animals of all ages, whereas in the present study only calves were infested by this species.

Generally, infested animals do not express symptoms, mainly when the infestation intensity is low. Only calves showed local symptoms during this study, more precisely pruritus in $63 \%$ of the infested ones, which sometimes induced a depilation observed in $37 \%$ of these calves.

In the present study, infestation prevalence by chewing lice was low since all infested cattle but five calves were infested by sucking lice. Species of this group are more pathogenic since they cause anemia, whereas chewing lice only cause pruritus. Gharbi et al. (2013) mentioned a different trend in small farms as they found a higher prevalence of B. bovis (4\%) than of Anoplura ( $0.6 \%$ ). This could be explained by a potential use of ivermectin by smallholders eliminating sucking lice. Ivermectin is forbidden in lactating cows and was never used in the studied farm. Other authors reported a higher infestation by chewing lice from $26.7 \%$ (Colwell et al., 2001) to $97 \%$ (Milnes et al., 2003).
The highest infestation prevalence was observed during this study for H. eurysternus (11.4\%). Infestation prevalence by this species can be very variable. Hussain et al. (2006) thus reported a prevalence varying between 1.9 and $94 \%$ in Pakistan.

The dorsal line was the anatomical region that was the most infested by $B$. bovis. Similar findings were reported in the southwest of England where the parasites were present on the dorsal line of $86.4 \%$ of the infested animals (Milnes et al., 2003). H. eurysternus was only found on the tail as also reported by Matthysse (1946). On the other hand, $L$. vituli infested the whole body without any preference, as also reported by Scharff et al. (1962). It is important to know the exact anatomical localization of lice since it allows the farmer to use insecticides only on infested body parts, allowing then an increase of the treatment effectiveness and a drastic reduction in the quantity of insecticides used.

The present study showed the low infestation prevalence and intensity in cattle in the studied farm, pointing out that the eradication of these parasites from such farms could be obtained at low cost. The results also showed that louse infestation is not a major health problem in the studied cattle farm. Animal health decision makers and field veterinarians should be informed about the clinical (anatomical localization, louse species) and epidemiological features (e.g. regional distribution, infection distribution according to age) of cattle infestation by lice. A standard program should be developed and implemented in louse-infected cattle farms with the aim to decrease the impact of these parasites that mainly affect calves, causing often symptoms of pruritus and depilation.

\section{Acknowledgments}

The study was financially supported by the project 'Bassin Laitier à Bizerte' (Institution de la recherche et de l'enseignement supérieur agricoles, ministère de l'Agriculture, des Ressources hydrauliques et de la Pêche) and by the Laboratoire d'épidémiologie d'infections enzootiques des herbivores en Tunisie : application à la lutte (ministère de l'Enseignement supérieur et de la Recherche scientifique et des Technologies de l'Information et de la Communication). The authors thank the farmers who agreed to let them handle their animals.

\section{Author contributions statement}

MG designed the study, participated in its planning and manuscript drafting; WL collected the data and drafted the first version of the manuscript; MZ participated in the study planning; MJ carried out parasite identification.

\section{Conflicts of interest}

The study was carried without any conflict of interest. 


\section{REFERENCES}

Bush A.O., Lafferty K.D., Lotz J.M., Shostak A.W., 1997. Parasitology meets ecology on its own terms: Margolis et al. revisited. J. Parasitol., 83 (4) 575-583, doi: 10.2307/3284227

Colebrook E., Wall R., 2004. Ectoparasites of livestock in Europe and the Mediterranean region. Vet. Parasitol., 120 (4): 251-274, doi: 10.1016/j.vetpar.2004.01.012

Colwell D.D., Clymer B., Booker C.W., Guichon P.T., Jim G.K., Schunich O.C., Wildman B.K., 2001. Prevalence of sucking and chewing lice on cattle entering feedlots in southern Alberta. Can. Vet. J., 42 (4): 281-285

Dorchies P., Duncan J., Losson B., Alzieu J.P., 2012. Parasitologie clinique des bovins. Med'Com Editions, Paris, France, 342 p.

Eydal M., Richter S.H., 2010. Lice and mite infestations of cattle in Iceland. Icel. Agric. Sci., 23: 87-95

Geden C.J., Rutz D.A., Bishop D.R., 1990. Cattle lice (Anoplura, Mallophaga) in New York: seasonal population changes, effects of housing type on infestations of calves, and sampling efficiency. J. Econ. Entomol., 83 (4): 1435-1438, doi: 10.1093/jee/83.4.1435

Gharbi M., Ben Abdallah H., Mbarek Y., Jedidi M., Darghouth M.A., 2013. Cross-sectional study of cattle lice infestation in the region of Nabeul in north-east Tunisia. Rev. Sci. Tech. Off. Int. Epizoot., 32 (3): 879-883, doi: 10.20506/rst.32.2.2208

Hornok S., Hofmann-Lehmann R., Fernández de Mera I.G., Meli M.L., Elek V., Hajtós I., Répási A., et al., 2010. Survey on blood-sucking lice (Phthiraptera: Anoplura) of ruminants and pigs with molecular detection of Anaplasma and Rickettsia spp. Vet. Parasitol., 174 (3-4): 355-358, doi: 10.1016/j.vetpar.2010.09.003

Hussain M.A., Khan M.N., Iqbal Z., Sajid M.S., Arshad M., 2006. Bovine pediculosis, prevalence and chemotherapeutic control in Pakistan. Livest. Res. Rural Dev., 18: 145
Kakar M.N., Kakarsulemankhel J.K., 2009. Prevalence of lice species on cows and buffaloes of Quetta, Pakistan. Pak. Vet. J., 29 (1): 49-50

Kumsa B., Bekele M., 2008. Lice infestation on cattle in Endegagn District, Southern Ethiopia: species composition, prevalence and seasonal pattern. Bull. Anim. Health Prod. Afr., 56 (3): 213-222, doi: 10.4314/bahpa. v56i3.43285

Levot G., 2000. Resistance and the control of lice on humans and production animals. Int. J. Parasitol., 30 (3): 291-297, doi: 10.1016/S00207519(99)00203-9

Matthysse J.G., 1946. Cattle lice, their biology and control. Bull. Cornell Univ. Agric. Exp. Station, 832: 67 p.

Milnes A.S., Green L.E., 1999. Prevalence of lice on dairy cattle in England and the bordering counties of Wales. Vet. Rec., 145 (13): 357-362, doi: 10.1136/vr.145.13.357

Milnes A.S., O'Callaghan C.J., Green L.E., 2003. A longitudinal study of a natural lice infestation in growing cattle over two winter periods. Vet. Parasitol., 116 (1): 67-83, doi: 10.1016/S0304-4017(03)00208-5

Price M.A., Graham O.H., 1997. Chewing and sucking lice as parasites of mammals and birds. U.S. Dep. Agric., Agric. Tech. Bull. No. 1849. Washington DC, USA, 309 p.

Sands B., Ellse L., Mitchell S., Sargison N.D., Wall R., 2015. First report of deltamethrin tolerance in the cattle chewing louse Bovicola bovis in the UK. Vet. Rec., 176 (9): 231, doi: 10.1136/vr.102777

Sanjay K., Prasad K.D., 2004. Prevalence of common ectoparasites infecting cattle and buffaloes in some areas of Jharkhand. Indian J. Anim. Sci., 74 (9): 938-939

Scharff D.K., 1962. An investigation of the cattle louse problem. J. Econ. Entomol., 55 (5): 684-688, doi: 10.1093/jee/55.5.684

Sraïri M.T., Benyoucef M.T., Kraiem K., 2013. The dairy chains in North Africa (Algeria, Morocco and Tunisia): from self sufficiency options to food dependency? SpringerPlus, 2: 162, doi: 10.1186/2193-1801-2-162

\section{Résumé}

Gharbi M., Labibi W., Jedidi M., Zouari M. Infestation des bovins par les poux au nord de la Tunisie

La présente étude a été réalisée entre octobre 2014 et janvier 2015 sur 622 bovins appartenant à un élevage bovin laitier au nord de la Tunisie. Chaque animal a été examiné une fois afin de détecter la présence de poux. La prévalence de l'infestation a été estimée à 14,3\% (89/622). Trois espèces de poux ont été collectées : Linognathus vituli $(2,7 \%)$, Haematopinus eurysternus $(11,4 \%)$ et Bovicola bovis $(0,8 \%)$. La prévalence de co-infestation était de $0,6 \%$ et concernait $B$. bovis et $L$. vituli, récoltés chez quatre veaux (trois mâles et une femelle). Les veaux étaient infestés par les trois espèces de poux, $L$. vituli $(17,5 \%), B$. bovis $(5,2 \%)$ et $H$. eurysternus $(1,0 \%)$, alors que les adultes étaient infestés uniquement par $H$. eurysternus $(13,3 \%)$. Tous les spécimens de $H$. eurysternus ont été retrouvés au niveau de la queue des animaux, tandis que $L$. vituli était présent sur tout le corps. B. bovis était observé sur la partie antérieure du corps, principalement la région dorsale $(60 \%)(p<0,05)$. Des signes cliniques n'ont été observés que chez les veaux âgés de moins de six mois, les animaux infestés présentant du prurit (63\%) et des dépilations (37\%).

Mots-clés : bovin, Phthiraptera, Linognathus vituli, Bovicola bovis, Haematopinus eurysternus, Tunisie

\section{Resumen}

Gharbi M., Labibi W., Jedidi M., Zouari M. Infestación del ganado por piojos en el norte de Túnez

El estudio que se reporta se llevó a cabo entre octubre 2014 y enero 2015 e incluyó 622 bovinos pertenecientes a una finca lechera en el norte de Túnez. Cada animal fue examinado una vez para la presencia de piojos. La prevalencia de infestación se estimó en 14.3\% (89/622). Se recolectaron tres especies de piojos: Linognathus vituli $(2,7 \%)$, Haematopinus eurysternus $(11,4 \%)$ y Bovicola bovis $(0,8 \%)$. La prevalencia de coinfestación fue de 0,6 \% y concernió sólo $B$. bovis y $L$. vituli, recolectados en cuatro terneros (tres machos y una hembra). Los terneros estaban infestados con tres especies $L$. vituli $(17,5 \%), B$. bovis $(5,2 \%)$ y $H$. eurysternus $(1,0 \%)$, mientras que los adultos estaban infestados únicamente por $H$. eurysternus $(13,3 \%)$. Todos los parásitos $H$. eurysternus fueron encontrados en la cola de los animales, mientras que $L$. vituli estaba presente en todo el cuerpo. B. Bovis infestó las partes anteriores del cuerpo, principalmente la región dorsal $(60 \%)(p<0,05)$. Los signos clínicos fueron observados únicamente en terneros de menos de seis meses. Los terneros infestados presentaron prurito $(63 \%)$ y depilación $(37 \%)$.

Palabras clave : ganado bovino, Phthiraptera, Linognathus vituli, Bovicola bovis, Haematopinus eurysternus, Túnez 